\title{
The effect of visitor number and spice provisioning in pacing expression by jaguars evaluated through a case study
}

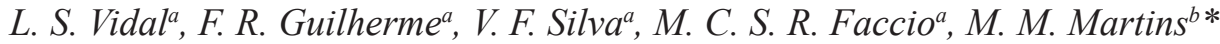 \\ and D. C. Briani ${ }^{c}$ \\ ${ }^{a}$ Centro Universitário de Araraquara - Uniara, Rua Voluntários da Pátria, 1309, \\ Centro, CEP 14801-320, Araraquara, SP, Brazil \\ bUniversidade de Santo Amaro - UNISA, Rua Professor Enéas Siqueira Neto, 340, \\ Jardim das Imbúias, CEP 04829-300, São Paulo, SP, Brazil \\ ${ }^{\mathrm{c}}$ Claretiano Faculdade, Avenida Santo Antônio Maria Claret, 1724, Cidade Claret, \\ CEP 13503-257, Rio Claro, SP, Brazil \\ *e-mail: milenemartins@terra.com.br
}

Received: November 1, 2014 - Accepted: February 23, 2015 - Distributed: May 31, 2016

(With 2 figures)

\begin{abstract}
Captive animals exhibit stereotypic pacing in response to multiple causes, including the inability to escape from human contact. Environmental enrichment techniques can minimize pacing expression. By using an individual-based approach, we addressed whether the amount of time two males and a female jaguar (Panthera onca) devote to pacing varied with the number of visitors and tested the effectiveness of cinnamon and black pepper in reducing pacing. The amount of time that all jaguars engaged in pacing increased significantly with the number of visitors. Despite the difference between the males regarding age and housing conditions, both devoted significantly less time to pacing following the addition of both spices, which indicates their suitability as enrichment techniques. Mean time devoted to pacing among the treatments did not differ for the female. Our findings pointed out to the validity of individual-based approaches, as they can reveal how suitable olfactory stimuli are to minimizing stereotypies irrespective of particular traits.
\end{abstract}

Keywords: behavior, jaguar, pacing, Panthera onca, public exposure, spice provisioning.

\section{O efeito do número de visitantes e do provisionamento de especiaria na expressão do pacing por onças-pintadas avaliado por estudo de caso}

\begin{abstract}
Resumo
Animais cativos exibem a estereotipia pacing em resposta a múltiplos fatores, os quais incluem a incapacidade de escapar da exposição ao público. As técnicas de enriquecimento ambiental podem minimizar a expressão do pacing. Usando uma abordagem individual, nós investigamos se a extensão de tempo que dois machos e uma fêmea de onça-pintada (Panthera onca) dispendem com pacing variou em função do número de visitantes e testamos a eficácia da canela e da pimenta-do-reino na redução do pacing. A extensão de tempo em pacing aumentou significativamente com o número de visitantes para todos os indivíduos. Apesar da diferença entre os machos com relação à idade e às condições no cativeiro, ambos devotaram ao pacing menos tempo após a administração das duas especiarias, o que indica a adequabilidade dessas como técnicas de enriquecimento. Para a fềmea, o tempo médio dispendido com pacing não variou entre os tratamentos. Nossos resultados respaldam a validade da realização de abordagens individuais, uma vez que essas podem revelar o grau de eficácia dos estímulos olfativos na minimização de estereotipias independentemente de características particulares.
\end{abstract}

Palavras-chave: comportamento, onça-pintada, pacing, Panthera onca, exposição pública, especiaria no enriquecimento.

\section{Introduction}

The captive environment differs from the wild with respect to what animals experience. For instance, unlike wild animals, those housed in zoos are subjected to contact with unfamiliar humans. Public exposure can be one of the determining factors in the expression of stereotypic pacing (e.g., Carlstead, 1996; Davey, 2007; Mason et al., 2007; Morgan and Tromborg, 2007), the repetitive and apparently functionless locomotor behavior displayed by captive animals (Mason et al., 2007). Davey (2007) suggested that compared to small animals, large animals 
such as big cats are less prone to the negative effects of visitors. Therefore, one might expect varying results, as it seems to be the case. Increased pacing rates have been associated with the presence of large crowds in the vicinity of the enclosures for Indian leopards, Panthera pardus (Pocock, 1927) (Mallapur and Chellam, 2002). In contrast, Sellinger and $\mathrm{Ha}$ (2005) and Quirke et al. (2012) did not find positive associations for jaguars, Panthera onca (Linnaeus, 1758) and cheetahs, Acinonyx jubatus (Schreber, 1775), respectively. Overall, researchers concentrate on primates and a few other groups of species (Davey, 2007), but the effect of the visitor number on the display of pacing by large felids remains poorly addressed.

Increasing interest is emerging regarding the evaluation of currently used enrichment techniques that are alleged to reduce stereotypic behaviors (Swaisgood and Shepherdson, 2005, 2006; Shyne, 2006; Wells, 2009). For example, in a meta-analysis encompassing 54 studies Shyne (2006) reported that zoo animals exhibit less often stereotypic behaviors after the provision of an enrichment condition. While there is little doubt about the effectiveness of environmental enrichment on reducing stereotypic and abnormal behavior, the remaining challenge has been to determine suitable enrichment models for a given species. Different models have been introduced to felid enclosures, varying from novel food items or olfactory stimuli (Mellen and Shepherdson, 1997; McPhee, 2006; Bashaw et al., 2003; Wells and Egli, 2004; Skibiel et al., 2007; Quirke and O'Riordan, 2011; Resende et al., 2011) to objects or physical toys (Moreira et al., 2007). Until recently the provisioning of novel scents as enrichment alternatives for felids had been overlooked when compared to food items (Skibiel et al., 2007). However, adding odors has been shown to be successful in minimizing the time devoted to pacing (Skibiel et al., 2007; Quirke and O'Riordan, 2011; Resende et al., 2011).

Jaguars are the largest extant felid in the Americas (Nowell and Jackson, 1996) about which hardly any information regarding pacing is available. Sellinger and Ha (2005) found that jaguars increased pacing behavior in response to low-level noise, but not to visitor numbers. Three spices (cinnamon, chilli powder, and cumin) and four enrichment models (toy, food, sound, and scent) have been shown to reduce pacing in jaguars (Skibiel et al., 2007; Castillo-Guevara et al., 2012). Unfortunately, the separate effect of each spice or model was not tested by the researchers. The number of jaguars a given zoo is able to shelter is normally small, which precludes researchers from obtaining large sample sizes. However, zoos provide the opportunity to carrying out individual-based approaches. Here, we address the following questions regarding three captive jaguars: 1) Does exposure to an increasing number of visitors lead to a rise in the display of pacing? and 2) Does pacing expression reduce after the provisioning of spices? We predicted that pacing expression in jaguars would increase in accordance with visitor number. We also hypothesized that jaguars would respond positively to the provisioning of each spice by devoting less time to pacing.

\section{Material and Methods}

\subsection{Subjects and housing}

We tested all jaguars available at Parque Ecológico de São Carlos (PESC) in São Carlos, SP, Brazil: two adult males and one adult female. One of the males (B) was housed singly while the other male (T) and the female (A) were housed as a pair. Born at PESC, the males B and T were 5 and 11 years-old, respectively, at the start of the study. The female A was brought to the zoo after spending some time in an institution that shelters wild animals rescued from illegal trade. Therefore, her birthplace and age were unknown. The jaguars were $70 \mathrm{~kg}$ (both B and $\mathrm{T})$ and $50 \mathrm{~kg}(\mathrm{~A})$ in body size.

The area encompassed by each enclosure, one adjacent to the other, was $128 \mathrm{~m}^{2}$. These enclosures, separated by a concrete wall, were both partially covered by wooden sheds for shelter. A glass barrier covered the front part of each enclosure, allowing a full view of the inner side. The floor contained bare ground and grass interspersed with rocks and tree trunks. A few palm trees and shrubs provided the animals with shelter from sunlight and a hiding place from public view, respectively. The jaguars were fed red meat three days a week, and Wistar rat, Rattus norvegicus (Berkenhout, 1796) and chicken meat once and four times a month, respectively.

\subsection{Experimental protocol}

In the month prior to the start of the study, the jaguars were habituated to the presence of the observers. We collected behavioral data in two phases: 1) prior to the addition of the enrichment (baseline) from October 2006 to March 2007 and 2) following the addition of the enrichment from September 2007 to May 2008. Sampling was carried out on Saturdays from $0900 \mathrm{~h}$ to $1600 \mathrm{~h}$. Although we recognize that gathering data after the removal of the enrichment is important to evaluate to what extent the stimuli improved the animals' behavior (Bashaw et al., 2003), time and logistical constraints prevented us from doing so. Sampling was always performed under on-exhibit conditions, i.e., when the jaguars were exposed to visitors. In both phases we recorded behavioral data (see below) and the total number of visitors in the surroundings of the enclosures during the timespan of each sample period.

We used a focal animal sampling method (Altmann, 1974). The order in which the animals were sampled was randomized. Each focal individual was continuously observed during sample periods lasting two or three hours. We carried out 11 sample periods of $2 \mathrm{~h}$ and 6 periods of $3 \mathrm{~h}$ per animal in both phases. We thus collected $40 \mathrm{~h}$ of focal data per individual in each phase. No individual was sampled twice in a single day. In each sample period, we recorded the animal's identity, and with a cronometer, the extension of time (minutes) the animal engaged in pacing. Before starting data collection in phase $2,50 \mathrm{mg}$ of powdered cinnamon (Cinnamomum zeylanicum Blume.) or black pepper (Piper nigrum L.) was sprinkled over the tree trunks in the form of a scent trail. We selected these spices because they are readily purchasable and easily provided. One type of spice was provided on a Friday 
afternoon and left in the enclosure until the next Friday, when it was added again. We finished the cinnamon trials and after one week-interval, during which the zoo personnel cleaned the cages, we started the black pepper trials. This protocol adheres to the guidelines for the use of animals in research of the International Society for Applied Ethology.

\subsection{Data analysis}

Although using each sample period gathered for the same animal as a replication might be regarded as a pseudoreplication, we believe that the seven days that elapsed between two consecutive sampling periods lend a minimal level of independence to the observations. We used linear regression to test whether the $\log _{10}$-transformed number of visitors determined the time jaguars devoted to pacing. Data were transformed to minimize the discrepancy between very dissimilar values. The test of the effectiveness of olfactory enrichment involved a one-way analysis of variance (ANOVA) for each animal. We compared the mean time devoted to pacing by the same jaguar in the baseline and after the provisioning of each spice separately. Raw data were tested for homogeneity of variance using Bartlett's test (Zar, 1999) and transformed to their square root when necessary. When variance heterogeneity persisted, we tested the nontransformed data using the Kruskal-Wallis test. The difference between the effects of adding cinnamon or black pepper was tested by Tukey test when the previous test had been ANOVA or Newman-Keuls test when the previous test had been Kruskal-Wallis. The confidence level was set at $95 \%(\alpha=0.05)$ for all tests.

\section{Results}

The number of visitors in the vicinity of the enclosures in phase 1 varied from $0-177,0-231$, and $0-131$ during the sampling periods of $\mathrm{B}, \mathrm{T}$ and $\mathrm{A}$, respectively. The amount of time that all jaguars engaged in pacing increased significantly with the number of visitors $\left(\mathrm{R}^{2}=0.444 ; \mathrm{n}=17 ; P=0.003\right.$ for $\mathrm{B} ; \mathrm{R}^{2}=0.605 ; \mathrm{n}=17 ; P=0.000$ for $\mathrm{T}$ and $\mathrm{R}^{2}=0.724 ; \mathrm{n}=17$; $P=0.000$ for A; Figure 1). B, T and A devoted respectively $42.47 \pm 21.94 \mathrm{~min}($ mean $\pm \mathrm{sd}), 41.58 \pm 31.81 \mathrm{~min}$ and $1.94 \pm 3.38 \mathrm{~min}$ to pacing in the baseline. In phase 2 the number of visitors near the enclosures of $\mathrm{B}, \mathrm{T}$ and $\mathrm{A}$ varied from 0-164, 2-197 and 0-182, respectively. Following the provisioning of the scents, pacing display by $\mathrm{B}(\mathrm{F}=16.87$; $\mathrm{df}=2 ; P=0.00)$ and $\mathrm{T}$ (Kruskall-Wallis comparison $\mathrm{KW}$ $=10.54 ; P=0.005)$ decreased significantly (Figure 2$)$, a fall corresponding to around $73 \%$ and $89 \%$ in $\mathrm{B}$ and $\mathrm{T}$, respectively. Cinnamon and black pepper showed similar
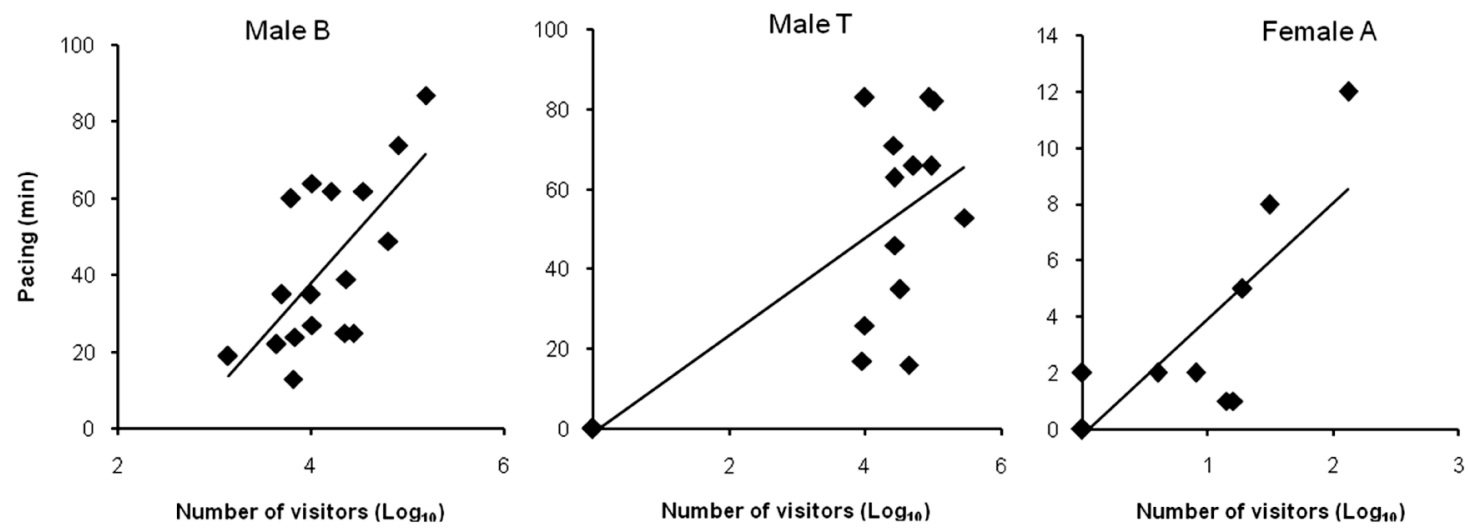

Figure 1. Total time spent in the expression of pacing by three jaguars as a function of the $\log _{10}$-transformed number of visitors. Regression slopes: 75.11 (Male B), 0.91 (Male T), and 0.18 (Female A).
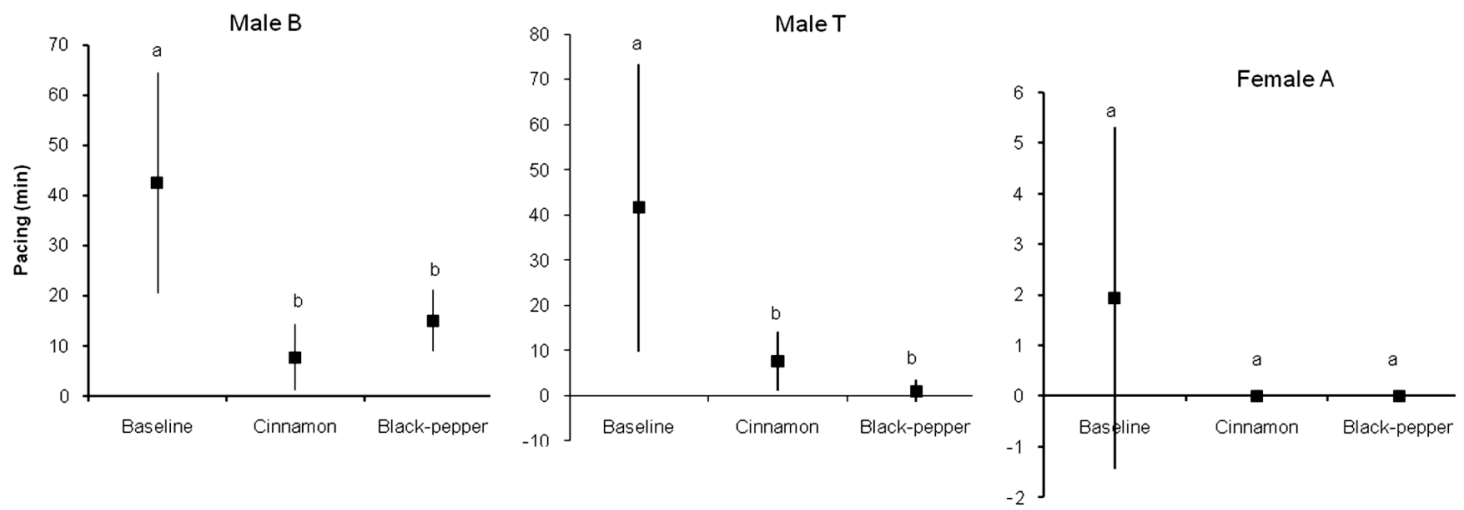

Figure 2. Mean $( \pm \mathrm{SD})$ time devoted to pacing by three jaguars in the baseline phase and after providing cinnamon and black pepper. Mean time devoted to pacing differing significantly from each other is indicated with a different letter symbol. 
effects on pacing expression by B (Tukey comparison $\mathrm{MS}=2.22 ; \mathrm{df}=26 ; P=0.273)$ and T (Newmann-Keuls comparison $\mathrm{MS}=632.060 ; P=0.608)$. In contrast, the difference in time devoted to pacing by A between the two phases was not significant $(\mathrm{F}=1.88 ; \mathrm{df}=2 ; P=0.172)$.

\section{Discussion}

The amount of time that jaguars dedicated to pacing was highly related to the number of visitors around their cages. This is in contrast to Sellinger and Ha's (2005) finding of a lack of association between visitor density and the frequency of pacing by an adult pair of jaguars. However, low-level noise (quiet talking) led to an increase of pacing behavior by the female (Sellinger and Ha, 2005). Despite the paucity of data, our results combined with those of Sellinger and Ha (2005), which also used an individual-based approach, suggest that the effect of public exposure on jaguars' stereotypic pacing may operate on an individual-basis, being ultimately determined by the sensitivity of the enclosure's occupant to one or more environmental stimuli. Although this argument may seem speculative, taking it as truth, one could ask why all the jaguars at PESC are sensitive to the increase in visitor numbers. Perhaps the shrubs planted inside both enclosures, which supposedly provide jaguars with hiding places, are ineffective. Alternatively, the reduced size of the enclosure could be operating in consort with public exposure, thereby enhancing pacing expression. Although some of the current available data lack statistical treatment, evidences suggest that confinement in enclosures leading to restricted movement may be harmful for felids (Bashaw et al., 2007; Moreira et al., 2007; Szokalski et al., 2012). For example, tigers housed in small enclosures paced more frequently than those in larger enclosures (Bashaw et al., 2007). The smallest enclosure (149 $\left.\mathrm{m}^{2}\right)$ in the investigation by Bashaw et al. (2007) is slightly larger than those in our study site $\left(128 \mathrm{~m}^{2}\right)$. On the other hand, the enclosure of the jaguar pair in Sellinger and Ha's (2005) study is smaller $\left(88 \mathrm{~m}^{2}\right)$ than ours, but these authors did not detect an effect of visitor number on pacing expression. We cannot disregard that the reduced "territory" of the jaguars we studied may influence the expression of pacing. However, enclosures vary in their structural complexity, and arrangements within enclosures may compensate for restriction of available space. Indeed, controlling for structural diversity when comparing animals from different zoos housed in enclosures of approximately similar size is difficult, and is therefore hardly ever done.

We found that the amount of time the male jaguars dedicated to pacing diminished after providing the spices. Both the cinnamon and black pepper trails were equally effective in reducing pacing expression. This suggests that these spices are suitable for the male jaguars, despite the difference between $B$ and $T$ regarding age $(5 \times 11$ years-old $)$ and housing conditions (isolated $\mathrm{x}$ paired). The female increased pacing in accordance with visitor density, but her mean pacing time did not differ in the two phases. Actually,
A displayed short pacing bouts in the baseline phase, a pattern that was not observed in the males. Two prevailing circumstances in the baseline period may have caused that. First, despite our care towards preventing bias, we noted reduced visitor density around the enclosure of the pair in the sampling periods of A. The reason for this difference in visitor number is unknown, as the sampling of all animals was carried out at similar periods of the day. Second, the repetitive attempts of $\mathrm{T}$ to copulate with A may have led to an increase in inactivity on her part. Meanwhile, how far these conditions are associated to her unresponsiveness to the spice provisioning is an open question. Perhaps a study with female jaguars housed as singletons and as pairs should be conducted to test whether male behavior play a role in female low level or lack of pacing. Our data agree with previous studies reporting the addition of spices and a subsequent decrease in pacing displayed by felids (Wells and Egli, 2004; Skibiel et al., 2007; Resende et al., 2011). However, unlike our study, these investigators report their outcomes for all animals combined, which prevents uncovering the possible influence of individual attributes.

Although apparently multiple factors besides visitor number may underlie the display of pacing by jaguars, it is highly recommended that the husbandry staff in our study site implement strategies to counteract the visitor effect. For example, the replacement of the current glass barrier by a one-way viewing glass barrier should be considered. This measure should be followed by the use of effective wording on signs appealing to visitors not to knock on the glass barrier or not to make excessive noise.

Our results must be viewed with caution because of the reduced number of animals and total behavioral sampling of each animal. The results also have a limited scope because we do not have additional behavioral data rather than stereotypic pacing display. Moreover, we cannot evaluate whether other behaviors are affected by public exposure, as is the case with pumas, Puma concolor (Linnaeus, 1771): instead of affecting locomotion behavior, the high number of visitors and the noise they make increased the inactivity of an adult female and her 8-year-old daughter during the morning periods (Maia et al., 2012). Nevertheless, we found interesting outputs that add novelty to a poorly studied felid species. Visual contact with an increasing number of visitors led to extended pacing display in the studied jaguars. Despite differences between male jaguars regarding age and presence of a companion, either cinnamon or black pepper were suitable to reduce the expression of pacing in them. The unresponsiveness of the female jaguar to spice provisioning was likely associated to her prior reduced engagement in pacing. Despite the aforementioned constraints, our findings point out to the validity of investing efforts towards evaluating the effectiveness of novel scents through individual-based approaches. They may be useful in revealing how far olfactory stimuli are suitable to minimizing stereotypies irrespective of divergences in particular traits. Further research should test whether the usefulness reported in this case study can be generalized to other circumstances. 


\section{Acknowledgements}

We thank the director of the Parque Ecológico de São Carlos (PESC) for permission to carry out the study.

\section{References}

ALTMANN, J., 1974. Observational study of behaviour: sampling methods. Behaviour, vol. 49, no. 3, pp. 227-267. http://dx.doi. org/10.1163/156853974X00534. PMid:4597405.

BASHAW, M.J., BLOOMSMITH, M.A., MARR, M.J. and MAPLE, T.L., 2003. To hunt or not to hunt? A feeding enrichment experiment with captive large felids. Zoo Biology, vol. 22, no. 2, pp. 189-198. http://dx.doi.org/10.1002/zoo.10065.

BASHAW, M.J., KELLING, A.S., BLOOMSMITH, M.A. and MAPLE, T.L., 2007. Environmental effects on the behavior of zoohoused lions and tigers, with a case study of the effects of a visual barrier on pacing. Journal of Applied Animal Welfare Science, vol. 10, no. 2, pp. 95-109. http://dx.doi.org/10.1080/10888700701313116. PMid:17559318.

CARLSTEAD, K., 1996. Effects of captivity on the behavior of wild mammals. In: D.G. KLEIMAN, M.E. ALLEN, K.V. THOMPSON, S. LUMPKIN and H. HARRIS. Wild mammals in captivity: principles and techniques. Chicago: University of Chicago Press, pp. 317-333.

CASTILLO-GUEVARA, C., UNDA-HARP, K., LARA, C. and SERIO-SILVA, J.C., 2012. Enriquecimiento ambiental y su effecto en la exhibición de comportamientos estereotipados em jaguares (Panthera onca) del Parque Zoológico "Yaguar Xoo", Oaxaca. Acta Zoológica Mexicana, vol. 28, no. 2, pp. 365-377.

DAVEY, G., 2007. Visitor's effect on the welfare of animals in the zoo: a review. Journal of Applied Animal Welfare Science, vol. 10, no. 2, pp. 169-183. http://dx.doi.org/10.1080/10888700701313595. PMid:17559323.

MAIA, C.M., VOLPATO, G.L. and SANTOS, E.F., 2012. A case study: the effect of visitors on two captive pumas with respect to the time of the day. Journal of Applied Animal Welfare Science, vol. 15, no. 3, pp. 222-235. http://dx.doi.org/10.1080/10888705 .2012.683758. PMid:22742199.

MALLAPUR, A. and CHELLAM, R., 2002. Environmental influences on stereotypy and the activity budget of Indian leopards (Panthera pardus) in four zoos in Southern India. Zoo Biology, vol. 21, no. 6, pp. 585-595. http://dx.doi.org/10.1002/zoo.10063.

MASON, G., CLUBB, R., LATHAM, N. and VICKERY, S., 2007. Why should we use environmental enrichment to tackle stereotypic behaviour? Applied Animal Behaviour Science, vol. 102, no. 3-4, pp. 163-188. http://dx.doi.org/10.1016/j.applanim.2006.05.041.

MCPHEE, M.E., 2006. Intact carcasses as enrichment for large felids: effects on on- and off-exhibit behaviors. Zoo Biology, vol. 21, no. 1, pp. 37-47. http://dx.doi.org/10.1002/zoo.10033.

MELLEN, J.D. and SHEPHERDSON, D.J., 1997. Environmental enrichment for felids: an integrated approach. International Zoo Yearbook, vol. 35, no. 1, pp. 191-197. http://dx.doi. org/10.1111/j.1748-1090.1997.tb01209.x.

MOREIRA, N., BROWN, J.L., MORAES, W., SWANSON, W.F. and MONTEIRO-FILHO, E.L.A., 2007. Effect of housing and environmental enrichment on adrenocortical activity, behavior and reproductive cyclicity in the female tigrina (Leopardus tigrinus) and margay (Leopardus wiedii). Zoo Biology, vol. 26, no. 6, pp. 441-460. http://dx.doi.org/10.1002/zoo.20139. PMid:19360593.
MORGAN, K.N. and TROMBORG, C.T., 2007. Source of stress in captivity. Applied Animal Behaviour Science, vol. 102, no. 3-4, pp. 262-302. http://dx.doi.org/10.1016/j.applanim.2006.05.032.

NOWELL, K. and JACKSON, P., 1996. Wilds cats: status survey and conservation action plan. Gland: IUCN.

QUIRKE, T. and O'RIORDAN, R.M., 2011. The effect of different types of enrichment on the behaviour of cheetahs (Acinonyx jubatus) in captivity. Applied Animal Behaviour Science, vol. 133, no. 1-2, pp. 87-94. http://dx.doi.org/10.1016/j.applanim.2011.05.004

QUIRKE, T., O'RIORDAN, R.M. and ZUUR, A., 2012. Factors influencing the prevalence of stereotypical behaviour in captive cheetahs (Acinonyx jubatus). Applied Animal Behaviour Science, vol. 142, no. 3-4, pp. 189-197. http://dx.doi.org/10.1016/j. applanim.2012.09.007.

RESENDE, L.S., GOMES, K.C.P., ANDRIOLO, A., GENARO, G., REMY, G.L. and RAMOS JUNIOR, V.A., 2011. Influence of cinnamom and catnip on the stereotypical pacing of oncilla cats (Leopardus tigrinus) in captivity. Journal of Applied Animal Welfare Science, vol. 14, no. 3, pp. 247-254. http://dx.doi.org/10 .1080/10888705.2011.576981. PMid:22044295.

SELLINGER, R.L. and HA, J.C., 2005. The effects of visitor density and intensity on the behavior of two captive jaguars (Panthera onca). Journal of Applied Animal Welfare Science, vol. 8, no. 4, pp. 233-244. http://dx.doi.org/10.1207/s15327604jaws0804_1. PMid: 16436028

SHYNE, A., 2006. Meta-analytic review of the effects of enrichment on stereotypic behavior in zoo mammals. Zoo Biology, vol. 25, no. 4, pp. 317-337. http://dx.doi.org/10.1002/zoo.20091.

SKIBIEL, A.L., TREVINO, H.S. and NAUGHER, K., 2007. Comparison of several types of enrichment for captive felids. Zoo Biology, vol. 26, no. 5, pp. 371-381. http://dx.doi.org/10.1002/ zoo.20147. PMid:19360587.

SWAISGOOD, R. and SHEPHERDSON, D., 2005. Scientific approaches to enrichment and stereotypies in zoo animals: what's been done and where should we go next? Zoo Biology, vol. 24, no. 6, pp. 499-518. http://dx.doi.org/10.1002/zoo.20066.

SWAISGOOD, R. and SHEPHERDSON, D., 2006. Environmental enrichment as a strategy for mitigating stereotypies in zoo animals: a literature review and meta-analysis. In: G.J. MASON and J. RUSHEN. Stereotypic animal behaviour: fundamentals and applications to welfare. 2nd ed. Wallingford: CAB International, pp. 256-285.

SZOKALSKI, M.S., LITCHFIELD, C.A. and FOSTER, W.K., 2012. Enrichment for captive tigers (Panthera tigris): current knowledge and future directions. Applied Animal Behaviour Science, vol. 139, no. 1-2, pp. 1-9. http://dx.doi.org/10.1016/j. applanim.2012.02.021.

WELLS, D.L. and EGLI, J.M., 2004. The influence of olfactory enrichment on the behaviour of captive black-footed cats, Felis nigripes. Applied Animal Behaviour Science, vol. 85, no. 1-2, pp. 107-119. http://dx.doi.org/10.1016/j.applanim.2003.08.013.

WELLS, D.L., 2009. Sensory stimulation as environmental enrichment for captive animals: a review. Applied Animal Behaviour Science, vol. 118, no. 1-2, pp. 1-11. http://dx.doi.org/10.1016/j. applanim.2009.01.002.

ZAR, J.H., 1999. Biostatistical analysis. 4th ed. New Jersey: Prentice Hall. 